\title{
Conference briefings
}

\section{World Congress of Psychiatry, Athens, 12-19 October 1989}

\author{
Geofrey Wallis, Consultant Psychiatrist, Fulford Grange Hospital, Micklefield Lane, \\ Rawdon, Leeds LS19 6BA
}

"The ideas of ancient Greek thinkers frequently appear modern, vivid and moving for novel developments in our field."

Thus spake Professor C. N. Ballas in a symposium at this Athens Congress, where Hippocrates might have been pleased with an emphasis, if not on black or yellow bile, on physical aetiology and treatment and on doctors working individually with patients rather than revealing secrets to team members. So too the ancient Olympic athletes might have been impressed to see that the Congress was held in the Peace and Friendship Stadium, a curious structure with a roof concave upwards on the coast near the Piraeus, designed primarily for athletics. Greeks now hope that the stadium will advance the bid of Athens to be the venue for the hundredth anniversary in 1996 of the first of the modern Olympic games.

The organisers had hoped that a convention centre would be built in time for the congress and this stadium was the only complex in Athens available that was large enough. Direction-finding guides within the building were mainly to different athletic departments, so that we had great difficulties in route-finding. The arena was divided by enormous brown curtains into four sections, one of which accommodated the main plenary sessions. For lectures given in one's own language, the acoustics in this vast space were appalling until a chance discovery revealed that one could hear more clearly through the simultaneously translating apparatus even when there was no need for translation. Information to this effect from the organisers would have tremendously heightened the comprehension of the audience.

From 64 countries came some 5,000 psychiatrists with 1,000 companions. There were 14 plenary sessions, three lectures by distinguished people, 170 symposia, 43 special sessions, 40 new research sessions, 133 free communication sessions, 24 video and film presentations, 18 workshops, and 50 poster sessions. The total number of papers exceeded 2,400 . There were numerous exhibitions by pharmaceutical companies, publishers and retailers and one by the Eginition Hospital, which is the hospital for the Department of Psychiatry of the University of Athens.
Hotels scattered far from the stadium accommodated participants who, even with the help of not inexpensive taxis, wasted many hours owing to inadequacy of transport and the 'mazelikeness' of the stadium. Participants lost most of the first day because for some hours no programmes or other documents were available and then they become embroiled in prolonged physical struggles, reminiscent of famine scenes, for lunch. One at a time little catering vans arrived at the stadium but their loads did not feed more than a few. The organisers apologised for this débâcle but a few days later the lunch queueing time was an hour.

On the other hand, organisation for the scientific sessions, provided one could find them, was slick and pleasant. Speakers about to perform saw their slides reassuringly projected on to a tiny screen in the right order and the right way up. The only serious defect in the sessions without simultaneous translation, which was available for major symposia only, was that presenters might give their papers in any language.

The pharmaceutical companies promoted some well publicised and attractively presented sessions that told of new therapies which could become established in future. The so-called reversible type $A$ as opposed to type B monoamine oxidase inhibitors (RIMAs) appeared to be more selective, have fewer incompatibilities with other substances and be generally safer than the ones now dubbed irreversible. Clozapine, described as a dibenzodiazepine that has been under investigation for nearly 30 years, may hold great promise for the treatment of schizophrenics who have not responded to other medication, but causes fever in $13 \%$ and agranulocytosis in $2 \%$ of patients. The agranulocytosis usually resolves if it is detected early and medication promptly stopped. As a successor to the benzodiazepines we heard that the first of the cyclopyrrolones was zopiclone, a substance with all the possible virtues and none of the vices of hypnotics. Time will tell. New serotonin uptake inhibitors promoted in different sessions were citalopram and sertraline. We heard too 
that buspirone, an azaspiro-decanedione was a serotonin agonist which relieved both anxiety and depression. Another antidepressant, tianeptine, was evidently novel in that it acted on the hypothalamopituitary adrenal axis. Under investigation in animals is piracetam, "the prototype of the nootropics", which might improve cholinergic transmission and therefore cognitive function. At times in sessions on these putative remedies promotional enthusiasm outweighed scientific evaluation even if there was literature to show that the presenters had done good double blind trials.

Dr Ann Streissguth from Washington gave a marvellous talk on the foetal alcohol syndrome. A squash court made a surprisingly good setting for videotape presentations, notably one on leucotomy by Dr Paul Bridges. Talks on social psychiatry were on the whole bland. As far as I could ascertain there was only one paper-by three psychiatrists from Washington, USA - on compulsory treatment in the community. Again there was only one - by Dr Adrian Grounds of Cambridge - that mentioned the controversy over whether a diagnosis of psychopathy should qualify for detention in hospital.

Over-running of time by eminent speakers led to comic relief. Sir Martin Roth's appearing to suggest at one moment that his talk was coming to an end and at the next that it might go on ad infinitum put his chairman, Professor Jules Angst, into a ferment of gesticulating indecision as he stood behind Sir Martin and wondered whether he should try to stop him. Professor George Lyketsos, when his chairman, no less than our own President, suggested that he should conclude, responded by asking the chairman for a glass of water to enable him to continue! The President complied.

Sidney Bloch (Psychiatric Bulletin, March 1990,14, 129-133) has written vividly of how the World Psychiatric Association at this Congress conditionally readmitted Russia. Professor Nikolai Zharikov, head of the Russian delegation and a pleasantly approachable man, was delighted with such an outcome. Likewise Rosalind Ramsay (Psychiatric Bulletin, March 1990, 14, 134-135) has described the Leros scandal which, apart from a paper on a questionnaire assessment of the Leros patients by a combined Guy's Hospital and Athens team, barely featured in the scientific proceedings of the Congress. We have since heard that progress in the Leros Hospital has virtually ceased because no psychiatrists want to work there. Should we not have qualms about the conditions, perhaps not much better than those in Leros, in which we keep some of our own severely mentally impaired patients?

As a result of elections at the Congress warmest congratulations are due to Professor Robert Priest on becoming one of four European members of the
WPA's Committee. The new President, relieving Professor Costa Stefanis of Athens, is another Costa, Professor da Costa Silva of Brazil, and the PresidentElect is Professor Felice Lieh-Mak of Hong Kong. She was the first woman to be a member of the WPA's Executive Committee and, having worked in the UK before she went to Hong Kong, is a Fellow of our College. Professor López-Ibor Alino takes over from Professor Fini Schulsinger of Copenhagen as Secretary-General.

The transport difficulties and very uneven distribution of food and wine marred a promising evening on the waterfront of the port of Mikrolimano beside the Peace and Friendship Stadium. The Congress dinner was better but even then, the Athens Hilton could not accommodate all the participants together, so that the speeches had to be relayed from one compartment to another.

The language for a production of Euripides' Electra in the quarter-arena of the Stadium was Greek but, with the help of much English explanation, one could fairly easily follow the drama. A row of interpreters' kiosks spoiled the scene, which would have been wonderful in a Greek or Roman theatre. One curiosity in the plot is that Electra does not have to go on trial although she joined with her brother, Orestes, in murdering their mother, Clytaemnestra. Orestes and his friend Pylades also murdered Clytaemnestra's lover. In this version of the story the Gods, acting as judge and jury, found Orestes not responsible for his actions because in his share of the murders he was seeking justifiable vengeance under the command of Apollo. The murder of Clytaemnestra was the third in Agamemnon's family. In the UK now some $40 \%$ of homicides occur in the family.

Surprising cancellation of sightseeing tours, allegedly owing to lack of support, gave your correspondent the opportunity to visit the original Athenian Agora, a complex of administration buildings around a market. One of the buildings was still in excellent condition. Although the custodian kept blowing his whistle to clear us out for closing time in the mid-afternoon, the place, far from being frightening, was pleasantly tranquillising. One wonders why the Athenians make so little of it as an attraction to visitors.

Locations for preceding World Congresses were Mexico, Honolulu and Vienna. The most successful was the one in Honolulu because there excellent lecture theatres of many sizes and hotels were all within easy walking distance of each other. The lesson is obvious and one wonders how the Congress will fare in 1995 in Hong Kong.

Whatever the ups and downs of this Congress, all the participants will surely be happy to pay a thankful tribute not only to the psychiatric acumen but also to the great warmth, kindness and generosity of our Athenian hosts. 